\title{
The Potential Risk of Viral Transmission Among Flying Foxes, Domestic Animals, and Humans in Southern Coast of West Java, Indonesia
}

\author{
Chaerul Basri ${ }^{1,3, a),}$ Etih Sudarnika ${ }^{1)}$, Abdul Zahid ${ }^{1)}$, Srihadi Agung Priyono ${ }^{1)}$,Retno D. \\ Soejoedono ${ }^{1)}$, \\ Eko M. Z. Arifin ${ }^{2)}$ Heru Susetya $^{3)}$, Bambang Sumiarto ${ }^{3)}$, Yupadee Hengjan ${ }^{4)}$, Keisuke Iida ${ }^{4)}$, \\ Hitoshi Takemae ${ }^{4)}$, Eiichi Hondo ${ }^{4)}$ \\ 1)Department of Animal Infectious Diseases and Veterinary Public Health, Faculty of \\ Veterinary Medicine, Bogor Agricultural University. Bogor. Indonesia. \\ 2)Livestock, Fisheries and Marine Services. Garut District. Indonesia. \\ 3)Department of Veterinary Public Health, Faculty of Veterinary Medicine. GadjahMada \\ University. Yogyakarta. Indonesia. \\ 4)Laboratory of Animal Morphology. Nagoya University. Nagoya 464-8601. Japan.
}

${ }^{a)}$ Corresponding author: chaerulbasri@yahoo.com

\begin{abstract}
Flying foxes have been considered to be involved in the transmission of serious infectious diseases to humans. This study aimed to know the direct and/or indirect contacts of flying foxes that live in the Indonesian natural conservation area, with domestic animals and humans living in the surrounding area, by the questionnaire. A survey of 150 respondents in 10 villages have been made.The area was grouped into; 1 . inside the conservation area and within $1 \mathrm{~km}$ from the outer border of the conservation area, 2. 1-5 km and 3. 5-10 km away from the border.The respondents are consisted of community leaders, religious leaders, youth leaders, children health centres officers, and farmers/fisherman group leaders, in each village. Data were collected by direct interview using a structured questionnaire consisted of the characteristics (the age, sex, and/or job) of respondents, the histories of contacts between flying foxes and humans, dogs, and domestic animals, and the knowledge about infectious diseases, mainly rabies, in flying foxes. This study found that the flying foxes from conservation area often enter theresidential areas at night to look for foods, especially during the fruit season. In the residential area, flying foxes directly contact with humans and a few contacts with domestic animals, only dogs. The persons, who touched flying foxes, seldom use personal protective equipment such as leather gloves, goggles and hats. The Residents living around conservation area mostly have poor knowledge about flying foxes and disease transmission. This situation shows that the population in this region is quite high risk for contracting infectious diseases from flying foxes.
\end{abstract}

Keyword: flying foxes, bats, diseases, zoonoses, Garut, Indonesia

\section{INTRODUCTION}

Flying foxes,fruits bats (megabats) in the genus of Pteropus, have been confirmed to play important roles in viral infectious diseases related to lyssavirus (Fraser et al. 1996), Hendra virus 
(Field et al. 2007), and/or Nipah virus (Chuaet al. 2002). Spillover of bat-borne zoonoses to domestic animals and humans has been caused by closer relationship between bats, domestic animals, and/or humans (Johnson et al. 2015).

The huge forest conservation area namely Leuweung Sancang $(2,157$ hectare is located in the south coast of Garut district (Maharadatunkamsi et al. 2015). Inside the conserved area, there are many big trees as roosting sites for thousands of flying foxes during day time. Garut district is still has problem with rabies both in humans and animals. In the period of 2005-2012 in West Java there are 4,027 cases of people bitten by a dog, causing 15 deaths and 6 of them in the district of Garut (Health Services of West Java Province 2016). This research aims to know the contacts among flying foxes, domestic animals, and humans in the residential area around roosting site, and the potential situation of viral transmission, especially rabies-related lyssavirus from flying foxes to domestic animals and/or humans, in and around Leuweung Sancang conservation area in Garut district.

\section{MATERIALS AND METHODS}

We focused on Leuweung Sancang forest conservation area in Cibalong subdistrict, Garut district, West Java Province, Indonesia. To reveal the relationship among flying foxes, domestic animals and humans in the point of the transmission of pathogens, we performed the questionnaire for the residents in and around the conservation area. The residents were randomly chosen in the limited distance range from the conservation area, that is, 1 . in and within $1 \mathrm{~km}(50$ residents), 2. from $1 \mathrm{~km}$ to $5 \mathrm{~km}$ (50 residents), 3. from 5-10 $\mathrm{km}$ (50 residents).

The respondents of this study are the persons aged over 15 years old and recognized as key informants of the villages. They include community leaders, religious leaders, youth leaders, children health center leaders, and farmer and/or fisherman group leaders.Data were collected through direct interviews using the structured questionnaire. The question posed in the questionnaire consists of five parts: the characteristics (the age, sex, and/or job) of respondents, the contacts between flying foxes and humans, between flying foxes and dogs, between flying foxes and domesticated animals, and experienced infectious diseases after they contact with flying foxes. Data from the questionnaire were analyzed using IBM SPSS Statistics for Windows, Version 21.0. IBM Corp, NY, US.

\section{RESULTS}

All respondents $(100 \%)$ said that they see dogs roaming around their houses. Most of them $(88.7 \%$ ) said that they saw dogs very often (> 5 dogs), almost every night. Around $86.7 \%$ of respondents believed that roaming dogs have owners, but the owners do not keep dogs on the leash. Only $7.3 \%$ of the respondents had cattles. A few respondents (5.3\%) only owns 1-2 cattle. 
The people in this area also has other domestic animals at home. They have other domestic animals include goats (13.3\%), sheep (22.5\%), chicken (80\%) and cats $(32.5 \%)$.

Flying foxes are mammals that considered actively foraging at night. During night time, flying foxes often get into residential areas to look for foods. All respondents (100\%) claimed to have seen flying foxes. Almost all of them (94.0\%) often saw flying foxes. Most of the respondents $(82.0 \%)$ also mentioned that flying foxes stay in the forest near their villages. Almost all $(98.7 \%)$ respondents had fruit trees around their houses, which include mangoes, papayas, soursops, kapoks, and/or coconuts.

Less than half $(44.7 \%)$ of the respondents have experienced frequent physical contact with flying foxes. Types of physical contact were hunting or holding $(95.8 \%)$ and eating (34.7\%).Only a few of respondents $(4.9 \%)$ used personal protective equipment (PPE) like leather gloves, glasses and/or hats to prevent from scratched or bitten when contacting with flying foxes. Fifty eight percent of respondents did not touch flying foxes. The most frequent physical contact between humans and flying foxes is hunting or holding (96.6\%), followed by cooking (83.9\%), cutting $(81.6 \%)$ and eating $(78.2 \%)$.

All respondents have never seen or heard any incidents related to humans being attacked by flying foxes $(0 \%)$. Nevertheless, $35.5 \%$ of respondents had seen or heard that flying foxes fell down from the tree or die. These incidents were recognized by many respondents $(75.5 \%)$ but was considered as rare events. Flying foxes sometimes seemed to fall down to the sea, or get electric shock by hanging on the electric wire in the residential area.

The incidence of sudden death cases in the population might be considered as some indication of the transmission of infectious diseases. The incidence of sudden death in the population around the roosting site of flying foxes was confirmed by nearly half $(42.0 \%)$ of respondents. Most (76.2\%) of the respondents stated that the incidence of human sudden death is very rare. Cases of sudden deaths in infants were mentioned by more than a quarter $(26.0 \%)$ of respondents. Nevertheless, the majority $(84.6 \%)$ of respondents stated that the death rate in children is classified as very rare.

Flying foxes, which entered residential areas may have had physical contact with domestic animals. A few respondents $(4.0 \%)$ claimed to have seen or heard that flying foxes had physical contact with dogs. Dogs sometimes hunt flying foxes during night time (33.3\%), and eat them $(66.7 \%)$. Nevertheless, none of the respondents claimed to have seen flying foxes attack dogs or cattle in their areas.

Infectious diseases might be transmitted to a domestic animal through physical contact with flying foxes. Sudden deaths in domestic animals, might be a sign of infection of pathogens to livestock. More than a quarter $(28.0 \%)$ of respondents had seen or heard sudden death cases of dogs in their residential areas where in the main reason of deaths is poisoning. Considerable number of respondents witnessed or heard sudden deaths of cattle $(34.0 \%)$, but these were very rare $(64.7 \%)$. 


\section{DISCUSSION}

Flying foxes have been known to be able to fly sustained long-distance (Breed et al. 2010). They could fly hundreds of kilometers occasionally from their camp, in search for food (Fleming and Eby, 2003). Flying foxes are known to have the ability to track food sources efficiently in the archipelago (McConkey and Drake 2007). During fruit season, flying foxes usually fly into the residential areas where fruits are located, and thus increasing the possibility of their contacts to other animals in Garut according to our present study.

Due to habitat overlapping, there was an increase in the physical contact between flying foxes and humans in Garut, Indonesia. The most common incidence of physical contact seems to occur when people hunt flying foxes. These people are actually in experienced in hunting and handling this species, which is quite different from Australia where in most of the people that had physical contact with a bat is the person who was trained in handling bats. In Brisbane, from 205 persons who reported potential ABL (Australian Bat Lyssavirus) exposure; volunteer animal handlers accounted for $39 \%$ of potential exposures, professional animal handlers for $14 \%$, community members who intentionally handled bats for $31 \%$, and community members with contacts initiated by bats for $4 \%$ (McCall et al., 2000).

A small proportion of the respondents who had contact with the bat have ever been scratched or biten. When in contact with flying foxes, almost ofthe people in the study area seldom use PPE (personal protective equipment) such as leather gloves, masks, and caps due to lack of awareness. It is because they are sure that bats that enter their residencial area were in good health and not likely to transmit infectious diseases to them. The persons never thought that flying foxes could be the carriers of zoonotic diseases.A survey of adults in New South Wales showed that $15.5 \%$ of 821 respondents had held bats, even though $42 \%$ of respondents have seen or heard warnings about holding bats (Paterson et al. 2014).

The results of the interviews in this study showed that people around the area of roosting site have never seen flying foxes who be have abnormally including abnormal flying behavior. Flying foxes that are infected with infectious diseases including rabies, may show symptoms of abnormal behavior such as abnormal flight.According to McColl et al. (2000), the clinical signs in infected bats with Lyssavirus were observed.Changes in reflexes, loss of appetite, the appearance of tremors and paralysis, and prostration are the main symptoms in bats.

There are many reported cases of sudden death in humans, both adults and infants, in the last 5 years in Garut. In adults, heart attacks, and the elderly are the most prevalent in sudden death cases. In infants, high fever for a long time without neurological symptoms is the most common cause of death. Every case showed that the patients had no history of contact with bats before their deaths. There was no typical symptoms of above mentioned bat related infectious diseases.

Sudden deaths in domestic animals, especially cattles, are also reported to have occurred frequently over the last 5 years. Most of them seemed to be caused by poisonning. Landowners 
often give chemicals to kill the plant / weed, which is given to cattle during grazing. Land owners feel unpleasant for that the land is used for grazing cattle, sometimes intentionally leave toxins in the land. Cows often uptake the toxins during eating plants/grasses, resulting in death. In addition, a variety of infectious diseases endemic in the area, such as BEF (Bovine Ephemeral Fever) and SE (Septicemia Epizootica), are often the cause of sudden death in domestic cattles in the area.

\section{REFERENCES}

Breed AC, Field HE, Smith CS, Edmonston J, Meers J, 2010. Bats Without Borders: LongDistance Movements and Implications for Disease Risk Management. EcoHealth 7:pp. 204212.

Chua KB, Koh CL, Hooi PS, Wee KF, Khong JH, Chua BH, Chan YP, Lim ME, Lam SK. 2002. Isolation of Nipah virus from Malaysian Island flying-foxes. Microbes Infect 4(2),pp.145151.

Field HE, Breed AC, Shield J, Hedlefs RM, Pittard K, Pott B, and Sumers PM, 2007.Epidemiological perspectives on Hendra virus infection in horses and flying foxes. Australian Veterinary Journal, 85(7):pp 268-270.

Fleming TH, and Eby P, 2003. Ecology of bat migration. In: BatEcology, Kunz TH, Fenton MB (editors), Chicago: The University of Chicago Press, pp 156-208

Fraser GC, Hooper PT, Lunt RA, Gould AR, Gleeson LJ, Hyatt AD, Russell and Kattenbelt J.A, 1996. Encephalitis caused by a lyssavirus in fruit bats in Australia. Emerg Infect Dis 2(4):pp327-31

Health Services of West Java Province. Health Profiles of 2015. 2016. http://www.diskes.jabarprov.go.id/index.php/arsip/categories/MTEz/profile-kesehatan

Johnson, CK, Hitchens PL, Evans TS, Goldstein T, Thomas K, Clements A., Joly Do, Wolfe ND, Daszak P, Karesh WB, and Mazet JK., 2015. Spillover and pandemic properties of zoonotic viruses with high host plasticity. Scientific reports, 5, p.14830. Available at: http://www.pubmedcentral.nih.gov/articlerender.fcgi?artid=4595845\&tool=pmcentrez\&ren dertype $=$ abstract $[$ Accessed December 8, 2016].

Maharadatunkamsi, Prakarsa T.B.P, and Kurnianingsih, 2015. Struture of mammals community in Leuweung Sancang Nature Reserve, regency of Garut, West Java.Zoo Indonesia, 24(1): pp 51-59.

McCall BJ, Epstein JH, Neill AS, Heel K, Field H, Barrett J, Smith GA, Selvey LA, Rodwell B, Lunt Ross, 2000. Potential Exposure to Australian Bat Lyssavirus, Quensland, 1996-1999. Emerging Infectious Diseases 6(3): pp. 259-264

McConkey, K.R. \& Drake, D.R., 2007. Indirect Evidence that Flying Foxes Track Food Resources Among Islands in a Pacific Archipelago. Biotropica, 39(3), pp.436-440. Available at: http://doi.wiley.com/10.1111/j.1744-7429.2007.00269.x [Accessed September 28, 2016]

Paterson, B.J. et al., 2014. Cross sectional survey of human-bat interaction in Australia: public health implications. BMC public health, 14, p.58. Available at: http://www.pubmedcentral.nih.gov/articlerender.fcgi?artid=3908316\&tool=pmcentrez\&ren dertype $=$ abstract. 
